\title{
Perception of the Beneficiaries of PMEGP: A Micro Level Study
}

\section{Shoba Ajithan $\mathbf{K}^{\star}$}

Government Arts College, Coimbatore-18, India

\begin{abstract}
Prime Minister's Employment Generation Programme (PMEGP) was launched in the year 2008 by merging the then Prime Minister's Rojgar Yojana (PMRY) and Rural Employment Generation Programme (REGP) schemes with a higher level of subsidy than PMRY and REGP. Under PMEGP, the beneficiary can directly approach Bank/Financial Institution along with his/her project proposal or it can be sponsored by Khadi and Village Industries Commission $(\mathrm{KVIC}) /$ Khadi and Village Industries Boards KVIBs/ District Industries Centre (DIC)/Panchayat Karyalayas etc. The applications received directly by the Banks are referred to the Task Force Committee, constituted at district level under the chairmanship of District Magistrate/Deputy Commissioner/Collector to scrutinize the applications based on the experience, technical qualification, skill, viability of the project etc. and hold quarterly meeting with the Banks at district level to review the status of the project proposals. During the last three years, since the launch of Prime Minister's Employment Generation Programme (PMEGP), the estimated number of employment opportunities created is 10.98 lakh persons (www.pib.in). Besides providing financial assistance, it compulsorily incorporates short-term Entrepreneurial Development Programme (EDP) training module, for comprehensively guiding the beneficiaries in launching and managing their micro enterprises. Today, Prime Minister's Employment Generation Programme is the most important self-employment programme of the Government and a household name in every corner of the country. The paper aims to evaluate Prime Minister's Employment Generation Programme in terms of the beneficiaries of the study group. The hypothesis tested was that income earned /problems faced by the beneficiaries didn't differ. The sample unit consists of 277 beneficiaries of the Prime Minister's Employment Generation Programme in Coimbatore district. Out of which 122 were females and 155 were male beneficiaries. The tools used to analyze the data were percentage, paired t test and KW test.
\end{abstract}

Keywords: Beneficiaries; Prime Minister’s Employment Generation Programme (PMEGP)

\section{Awareness of Prime Minister's Employment Generation Programme}

Prime Minister's Employment Generation Programme (PMEGP) is one of the schemes introduced by the central government for increasing self-employment among the eligible men and women of the country. The beneficiaries were questioned as to how they came to know about the function of the scheme, which the government had launched for the educated unemployed. The following Table 1 gives the various sources through which the respondents became aware of the Prime Minister's Employment Generation Programme.

In the manufacturing sector, out of the 93 respondents, $30.1 \%$ each of the self-employed women each came to know about the Prime Minister's Employment Generation Programme through friends and newspapers and $15.1 \%$ through agency. But in the service sector, about $31 \%$ of the women came to know about the scheme through agency, $20.7 \%$ each through newspapers and friends and $17.24 \%$ through relatives, internet and family members.

In the case of men beneficiaries, out of the 126 beneficiaries of the manufacturing sector, friends (35.7\%), others (19.84\%), newspaper (18.25\%), agency (13.5\%) and banks (12.69\%) made them aware of the scheme. In the service sector, others $(27.6 \%)$, banks and agency (20.68\% each), newspaper (17.24\%) and friends (13.79\%) played a vital role in creating awareness among the men beneficiaries. Others include internet, bank officials and family members. Among the women beneficiaries $27.9 \%$ each had come to know the functioning of the scheme through friends and newspapers. About $31.6 \%$ and $21.3 \%$ of self-employed men came to know about the scheme through friends and others respectively.

\section{Motivators}

The responses elicited through the interview schedule supplemented by the information received through personal interviews helped to identify the persons who were instrumental in motivating the women/ men to apply for the scheme. These agents were family members, friends, relatives, neighbors and other beneficiaries. In the women beneficiary group, sector wise analysis shows that in the manufacturing sector, family members' role is the main motivating force $(95.7 \%)$, followed by friends (1.07\%). Other beneficiaries constituted only $3.22 \%$ but relatives and neighbors did not influence the women beneficiaries. A similar trend was seen in service sector, where the role of family members was dominant (96.6\%), followed by friends $(3.44 \%)$ but relatives, other beneficiaries and neighbors did not exert any influence. In the case of men beneficiaries, about $81.7 \%$ in the manufacturing sector was motivated by their family members followed by friends (10.3\%), other beneficiaries (5.5\%), relatives $(1.58 \%)$ and neighbors (0.79\%). Similarly in service sector, family members (93.10\%) influence was dominant. About $3.44 \%$ each of friends and neighbors influenced the men beneficiaries to start the venture.

From the Table 2 it makes it clear that in the women beneficiary group, the support and help from the family members, especially

*Corresponding author: Shoba Ajithan K, Associate professor in Economics, Government Arts College, Coimbatore-18, India, Tel: 09442168909; E-mail: shobhaajithan@yahoo.com

Received February 01, 2013; Accepted May 14, 2014; Published May 19, 2014

Citation: Shoba Ajithan K (2014) Perception of the Beneficiaries of PMEGP: A Micro Level Study. J Socialomics 3: 109. doi:10.4172/2167-0358.1000109

Copyright: (c) 2014 Shoba Ajithan K. This is an open-access article distributed under the terms of the Creative Commons Attribution License, which permits unrestricted use, distribution, and reproduction in any medium, provided the original author and source are credited. 
Citation: Shoba Ajithan K (2014) Perception of the Beneficiaries of PMEGP: A Micro Level Study. J Socialomics 3: 109. doi:10.4172/21670358.1000109

Page 2 of 5

\begin{tabular}{|c|c|c|c|c|c|c|c|}
\hline Group & & & n benefic & & & beneficia & \\
\hline Awareness & ipation & Manufact-uring & Service & Total & Manufact-uring & Service & Total \\
\hline Friends & $N$ & $\begin{array}{c}28 \\
(30.10)\end{array}$ & $\begin{array}{c}6 \\
(20.68)\end{array}$ & $\begin{array}{c}34 \\
(27.86)\end{array}$ & $\begin{array}{c}45 \\
(35.71)\end{array}$ & $\begin{array}{c}4 \\
(13.79)\end{array}$ & $\begin{array}{c}49 \\
(31.61)\end{array}$ \\
\hline Newspaper & $N$ & $\begin{array}{c}28 \\
(30.10)\end{array}$ & $\begin{array}{c}6 \\
(20.68)\end{array}$ & $\begin{array}{c}34 \\
(27.86)\end{array}$ & $\begin{array}{c}23 \\
(18.25)\end{array}$ & $\begin{array}{c}5 \\
(17.24)\end{array}$ & $\begin{array}{c}28 \\
(18.06)\end{array}$ \\
\hline Radio/TV & N & $\begin{array}{c}2 \\
(2.15)\end{array}$ & $\begin{array}{c}0 \\
(0)\end{array}$ & $\begin{array}{c}2 \\
(1.63)\end{array}$ & $\begin{array}{c}0 \\
(0)\end{array}$ & $\begin{array}{c}0 \\
(0)\end{array}$ & $\begin{array}{c}0 \\
(0)\end{array}$ \\
\hline Agency & $N$ & $\begin{array}{c}14 \\
(15.05)\end{array}$ & $\begin{array}{c}9 \\
(31.03)\end{array}$ & $\begin{array}{c}23 \\
(18.8)\end{array}$ & $\begin{array}{c}17 \\
(13.49)\end{array}$ & $\begin{array}{c}6 \\
(20.68)\end{array}$ & $\begin{array}{c}23 \\
(14.83)\end{array}$ \\
\hline Banks & $N$ & $\begin{array}{c}10 \\
(10.75)\end{array}$ & $\begin{array}{c}3 \\
(10.34)\end{array}$ & $\begin{array}{c}13 \\
(10.65)\end{array}$ & $\begin{array}{c}16 \\
(12.69)\end{array}$ & $\begin{array}{c}6 \\
(20.68)\end{array}$ & $\begin{array}{c}22 \\
(14.19)\end{array}$ \\
\hline Others & $N$ & $\begin{array}{c}11 \\
(11.82)\end{array}$ & $\begin{array}{c}5 \\
(17.24)\end{array}$ & $\begin{array}{c}16 \\
(13.11)\end{array}$ & $\begin{array}{c}25 \\
(19.84)\end{array}$ & $\begin{array}{c}8 \\
(27.58)\end{array}$ & $\begin{array}{c}33 \\
(21.29)\end{array}$ \\
\hline Total & $\mathbf{N}$ & 93 & 29 & 122 & 126 & 29 & 155 \\
\hline
\end{tabular}

Source: Field survey. $\mathrm{N}-$ Number stated, Figures in brackets denote \% to column total

Table 1: Sources of awareness about prime minister's employment generation programme.

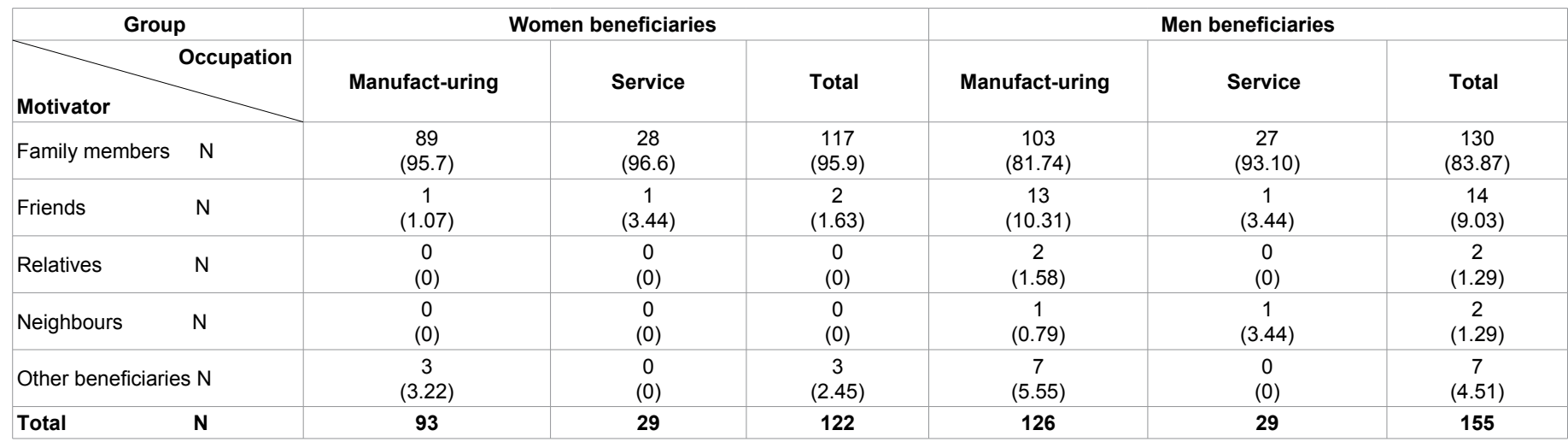

Source: Field survey. $\mathrm{N}-$ Number stated, Figures in brackets denote \% to column total

Table 2: Motivator wise classification of the beneficiaries.

parents and husbands (95.9\%) were crucial in applying for the scheme, followed by friends (1.63\%) and other beneficiaries (2.45\%). About $83.87 \%$ of men beneficiaries were influenced by family members followed by friends (9.03\%), other beneficiaries (4.51\%), relatives and neighbours $(1.29 \%$ each). These agents were instrumental in men beneficiaries for applying for the scheme.

Average monthly income of the beneficiaries before and after starting the units

The most pertinent aspect of the success of a scheme is its impact on income or earnings of its beneficiaries. A high level of employment in terms of time or work intensity has no meaning if it fails to generate income. Employment and unemployment are measured by the income criterion. So the validity of a scheme could be judged by the amount of income generated through business activities [1]. To analyze the impact of the scheme, data relating to monthly income is presented in the following Table 3 .

Before availing PMEGP the average monthly income of the women beneficiaries in the manufacturing and service sectors were Rs.5,118.28 and Rs.7,655.17 respectively but after availing PMEGP, their monthly income increased to Rs.20,806.45 and Rs.20,344.80 respectively. In case of men beneficiaries, before applying for PMEGP the average monthly income in the manufacturing sector was Rs.6,083.33 but after availing the loan, the average income increased to Rs.20,503.18. Similarly, in the service sector also the average income increased from Rs.5,827.59 to
Rs.21,431.03 after availing the loan. Overall, the beneficiaries' standard of living improved after availing PMEGP.

To find out whether there exists any significant difference in the average monthly income of the different groups between before and after availing PMEGP loan, paired sample' $t$ ' test was used. The calculated' $t$ ' values along with the theoretical values are presented in the following Table 4 .

As the calculated ' $\mathrm{t}$ ' values were greater than the theoretical ' $\mathrm{t}$ ' values at $5 \%$ level, it was concluded that there was significant difference in the average income earned before and after availing PMEGP loan by the women and men beneficiaries in the manufacturing and service sectors.

\section{Utilization of Income}

Prompt and timely repayment of loans advanced is a pre requisite for the sustainability of any scheme. The culture of availing loans under one or the other government scheme and treating it role is a common phenomenon. Most of the schemes which were introduced with very good intensions, failed to generate expected results due to pilferage and financial indiscipline. Irregularity in repayment or default also impinges upon the viability and sustainability of the financial institution [2]. The details regarding the utilization of income made by the women and men beneficiaries is analysed in the following Table 5 .

About $75.3 \%$ women beneficiaries in the manufacturing utilized the 
Citation: Shoba Ajithan K (2014) Perception of the Beneficiaries of PMEGP: A Micro Level Study. J Socialomics 3: 109. doi:10.4172/21670358.1000109

Page 3 of 5

\begin{tabular}{|c|c|c|c|c|c|c|}
\hline Group & \multicolumn{3}{|c|}{ Women beneficiaries } & \multicolumn{3}{|c|}{ Men beneficiaries } \\
\hline Period $\quad$ Occupation & Manufact-uring & Service & Total & Manufact-uring & Service & Total \\
\hline Before availing PMEGP & 5118.28 & 7655.17 & 5721.31 & 6083.33 & 5827.59 & 6035.48 \\
\hline After availing PMEGP & 20806.45 & 20344.83 & 20696.72 & 20503.18 & 21431.03 & 20676.77 \\
\hline Total & 93 & 29 & 122 & 126 & 29 & 155 \\
\hline
\end{tabular}

Source: Field survey. $\mathrm{N}-$ Number stated, Figures in brackets denote \% to column total

Table 3: Average Monthly Income of the Beneficiaries.

\begin{tabular}{|c|c|c|c|}
\hline Group & Calculated 't' Value & d.f & Theoretical ' $\mathbf{f}$ ' value \\
\hline Women beneficiaries Manufacturing & -8.867 & 92 & 1.96 \\
\hline Women beneficiaries Service & -5.774 & 28 & 1.96 \\
\hline Total & -10.350 & 121 & 1.96 \\
\hline Men beneficiaries Manufacturing & -10.264 & 125 & 1.96 \\
\hline Men beneficiaries Service & -5.589 & 28 & 1.96 \\
\hline Total & -10.350 & 154 & Rejejected Ho \\
\hline
\end{tabular}

Source: Calculations based on field survey.

Table 4: Monthly Difference in the Average Income Before And After Availing Pmegp Loan - 'T' Test.

\begin{tabular}{|c|c|c|c|c|c|c|}
\hline Group & \multicolumn{3}{|c|}{ Women beneficiaries } & \multicolumn{3}{|c|}{ Men beneficiaries } \\
\hline Activity $\quad$ Occupation & Manufact-uring & Service & Total & Manufact-uring & Service & Total \\
\hline Asset creation & $\begin{array}{c}34 \\
(36.6)\end{array}$ & $\begin{array}{c}9 \\
(31.03)\end{array}$ & $\begin{array}{c}43 \\
(35.24)\end{array}$ & $\begin{array}{c}60 \\
(47.6)\end{array}$ & $\begin{array}{c}6 \\
(20.7)\end{array}$ & $\begin{array}{c}66 \\
(42.6)\end{array}$ \\
\hline Domestic consumption & $\begin{array}{c}70 \\
(75.3)\end{array}$ & $\begin{array}{c}28 \\
(96.6)\end{array}$ & $\begin{array}{c}98 \\
(80.3)\end{array}$ & $\begin{array}{c}102 \\
(80.9)\end{array}$ & $\begin{array}{c}19 \\
(65.5)\end{array}$ & $\begin{array}{c}121 \\
(78.1)\end{array}$ \\
\hline Savings & $\begin{array}{c}4 \\
(4.3)\end{array}$ & $\begin{array}{c}0 \\
(0)\end{array}$ & $\begin{array}{c}4 \\
(3.3)\end{array}$ & $\begin{array}{c}1 \\
(0.79)\end{array}$ & $\begin{array}{c}1 \\
(3.45)\end{array}$ & $\begin{array}{c}2 \\
(1.3)\end{array}$ \\
\hline Reinvestment & $\begin{array}{c}93 \\
(100)\end{array}$ & $\begin{array}{c}29 \\
(100)\end{array}$ & $\begin{array}{c}122 \\
(100)\end{array}$ & $\begin{array}{c}126 \\
(100)\end{array}$ & $\begin{array}{c}29 \\
(100)\end{array}$ & $\begin{array}{c}155 \\
(100)\end{array}$ \\
\hline Loan repayment & $\begin{array}{c}93 \\
(100)\end{array}$ & $\begin{array}{c}29 \\
(100)\end{array}$ & $\begin{array}{c}122 \\
(100)\end{array}$ & $\begin{array}{c}126 \\
(100)\end{array}$ & $\begin{array}{c}29 \\
(100)\end{array}$ & $\begin{array}{c}155 \\
(100)\end{array}$ \\
\hline
\end{tabular}

Source: Field survey $\mathrm{N}$ - Number stated

Table 5: Distribution of the Beneficiaries Based On the Utilization of Income.

income for domestic consumption, $36.6 \%$ for asset creation and $4.3 \%$ for savings. In the service sector, about $96.6 \%$ and $31.03 \%$ respondents utilized their income for domestic consumption and asset creation respectively. Among the men beneficiaries in the manufacturing sector, about $80.9 \%$ utilized the income for domestic consumption, $47.6 \%$ for asset creation and $0.79 \%$ for savings. Similarly in the service sector, the men beneficiaries utilized their income for domestic consumption (65.5\%), asset creation (20.7\%) and savings (3.45\%). More than $75 \%$ and $35 \%$ of the beneficiaries utilized the income for domestic consumption and asset creation respectively. The entire women and men beneficiaries had partly utilized their derived income from their units for loan repayment and reinvestment. All the beneficiaries made a timely repayment after an initial moratorium of 3 months.

\section{Level of Satisfaction}

An opinion survey was conducted among the beneficiaries on the satisfaction level of the Prime Minister's Employment Generation Programme. They were asked to express their views as either 'fully satisfied' or 'partially satisfied' or 'not at all satisfied' or 'can't say'. The following Table 6 gives the responses stated by the beneficiaries on the level of satisfaction they had about the Prime Minister's Employment Generation Programme.

Out of the 93 self-employed women in the manufacturing sector, $94.6 \%$ were fully satisfied, $3.22 \%$ were partially satisfied and $1.07 \%$ was not at all satisfied with the scheme. In the case of service sector, among the 29 respondents, $93.1 \%$ were fully satisfied, followed by $3.4 \%$ each, who were partially satisfied and could not express their opinion.

Among the 126 men beneficiaries in the manufacturing sector, $91.3 \%$ were full satisfied, $3.96 \%$ were partially satisfied, $1.58 \%$ was not satisfied and $3.17 \%$ could not express their satisfaction level. However in the service sector all the men beneficiaries were fully satisfied with the scheme.

Combining all the beneficiaries together, the findings revealed that more than $90 \%$ of the beneficiaries were fully satisfied, $3.25 \%$ were partially satisfied and $1.08 \%$ was dissatisfied. Certain beneficiaries were partially satisfied and dissatisfied with the scheme because the loan amount sanctioned was much less than the amount demanded by them for their business. From the above analysis it can be stated that the scheme has elicited positive response from the study. Studies conducted by Chennappa and Shobha, $[1,3]$ had a similar finding in which $72 \%$ felt that Prime Minister's Rozgar Yojana was useful to the beneficiaries.

\section{Problems while Availing Government Assistance}

An attempt was made to find out the problems that the beneficiaries had in availing loans. During the course of the survey, ten problems were identified. They were, (i) delay in sanctioning loan, (ii) rate of interest, (iii)bureaucratic procedure, (iv) insufficient amount, (v) 
Citation: Shoba Ajithan K (2014) Perception of the Beneficiaries of PMEGP: A Micro Level Study. J Socialomics 3: 109. doi:10.4172/21670358.1000109

Page 4 of 5

\begin{tabular}{|c|c|c|c|c|c|c|c|}
\hline \multirow{2}{*}{\multicolumn{2}{|c|}{$\begin{array}{l}\text { Group } \\
\text { Occupation } \\
\text { Satisfaction }\end{array}$}} & \multicolumn{3}{|c|}{ Women beneficiaries } & \multicolumn{3}{|c|}{ Men beneficiaries } \\
\hline & & $\begin{array}{l}\text { Manufact- } \\
\text { uring }\end{array}$ & Service & Total & $\begin{array}{c}\text { Manufact- } \\
\text { uring }\end{array}$ & Service & Tot \\
\hline Fully & $\mathrm{N}$ & & $\begin{array}{c}27 \\
(93.10)\end{array}$ & $\begin{array}{r}11 \\
(94 .\end{array}$ & & & \\
\hline Partially sa & $\mathrm{N}$ & $\begin{array}{c}3 \\
(3.22)\end{array}$ & $\begin{array}{c}1 \\
(3.44)\end{array}$ & $\begin{array}{c}4 \\
(3.27)\end{array}$ & 5 & $\begin{array}{c}0 \\
(0)\end{array}$ & $\begin{array}{c}5 \\
(3.22)\end{array}$ \\
\hline Not at all s & $\mathrm{N}$ & $\begin{array}{c}1 \\
(1.07)\end{array}$ & 0 & $\begin{array}{c}1 \\
(0.81)\end{array}$ & 2 & $\begin{array}{c}0 \\
(0)\end{array}$ & $\begin{array}{c}2 \\
(1.29)\end{array}$ \\
\hline Can't say & $\mathrm{N}$ & $\begin{array}{c}1 \\
(1.07)\end{array}$ & $\begin{array}{c}1 \\
(3.44)\end{array}$ & $\begin{array}{c}2 \\
(1.63)\end{array}$ & $\begin{array}{c}4 \\
(3.17)\end{array}$ & $\begin{array}{l}0 \\
(0)\end{array}$ & $\begin{array}{c}4 \\
(2.58)\end{array}$ \\
\hline otal & $\mathbf{N}$ & 93 & 29 & 122 & 126 & 29 & 155 \\
\hline
\end{tabular}

Source: Calculations based on field survey

Table 6: Classification of the Beneficiaries Based On the Level of Satisfaction.

pledging of securities, (vi) commissions, (vii) political interference, (viii) red tapism, (ix) repayment procedure, and (x) repayment of loan.

The respondents were asked to state their opinion on the problems they faced while availing loan. Direct judgment method was used. For rating the responses given by the study group, the limited response category case was applied on a five point scale with the designated attributes such as 'fully agree', 'partly agree', 'neutral', 'partly disagree', and 'fully disagree'. Specified numerical weights were assigned to each attribute as $+2,+1,0,-1$, and -2 respectively. The average score for each response was calculated sector wise, and are presented in the following Table 7.

The average score will lie between +2 and -2 . If it is nearer to +2 , it implies that the beneficiaries fully agreed with the stated problem. If it is nearer to -2 , it implies that the respondents fully disagreed with the stated problem.

From the Table 7, it can be seen that the women beneficiaries in the service sector neither agreed nor disagreed on the statement of 'delay in sanctioning loans' $(0.10)$. Similarly the men beneficiaries in the service sector opined the same (0.07). The women beneficiaries in the manufacturing sector disagreed that the sanctioned amount was less $(-0.53)$. But the women in the service sector disagreed on the statement of 'inadequate loan amount', the score assigned being -0.52 . The respondents highly disagreed that they had the problem of 'bureaucratic procedure' or 'red tapism' in availing government assistance. The scores assigned for this were -1.70 and -1.80 in the manufacturing sector and -1.66 and -1.68 in the service sector respectively. There was no political interference, the score being -1.81 and -1.69 in manufacturing and service sectors respectively. As for 'repayment of loan' or 'repayment procedure' or 'interest rate charged', the respondents disagreed that they had problems. The analysis clearly reveals that there is no political interference in availing loan. But the process in sanctioning loan has to be modified and simplified.

Similarly among the men beneficiaries in the manufacturing and service sectors, for problems like 'repayment of loan', 'repayment procedure', 'interest rate charged', 'bureaucratic procedure', 'red tapism', 'political interference', 'pledging of securities' and 'commissions' the respondents disagreed to the above stated problems.

To find out whether there exists any significant difference in the problems faced by the women and men beneficiaries in the two sectors; Kruskal Wallis $\chi^{2}$ test was adopted. The null hypothesis tested was,

$\mathrm{H}_{\mathrm{o}}$ : The women and men beneficiaries in the two different sectors do not differ in the magnitude of the problems they faced, and

$\mathrm{H}_{\mathrm{a}}$ : They differ.
The following Table 8 gives the calculated $\chi^{2}$ values along with the theoretical $\chi^{2}$ values at 5 percent level of significance.

The opinion of the women, men beneficiaries and for the combined group between the two sectors significantly varied for the problem of delay in sanctioning loan. Only for this the calculated $\chi^{2}$ value exceeded the theoretical $\chi^{2}$ value. For all other problems the opinion expressed by the women, men beneficiaries and combined group between two sectors did not vary. The calculated $\chi^{2}$ values were less than theoretical $\chi^{2}$ values. But for the combined group, except for delaying in sanctioning loan, the opinion expressed by the respondents in the manufacturing sector did not differ in the opinion expressed by the respondents in the service sector.

\section{Conclusion}

In the organized sector, the employment opportunities have been stagnant. In such a back drop, PMEGP has become a boon to the unemployed youth. The beneficiaries were satisfied with the loan amount given. Their average monthly income had risen, thereby raising the living standards. Except for the delay in sanctioning the loan, the beneficiaries didn't face much problem, while availing the

\begin{tabular}{|c|c|c|c|c|c|c|}
\hline Group & \multicolumn{2}{|c|}{ Women beneficiaries } & \multicolumn{3}{|c|}{ Men beneficiaries } \\
\hline \multirow{2}{*}{ Occupation } & $\begin{array}{c}\text { Manufact- } \\
\text { uring }\end{array}$ & Service & All & $\begin{array}{c}\text { Manufact- } \\
\text { uring }\end{array}$ & Service & All \\
\cline { 2 - 7 } & $\begin{array}{c}\text { Average } \\
\text { Score }\end{array}$ & $\begin{array}{c}\text { Average } \\
\text { Score }\end{array}$ & $\begin{array}{c}\text { Average } \\
\text { Score }\end{array}$ & $\begin{array}{c}\text { Average } \\
\text { Score }\end{array}$ & $\begin{array}{c}\text { Average } \\
\text { Score }\end{array}$ & $\begin{array}{c}\text { Average } \\
\text { Score }\end{array}$ \\
\hline $\begin{array}{c}\text { Delay in } \\
\text { sanctioning } \\
\text { loans }\end{array}$ & -0.53 & 0.10 & -0.44 & -0.59 & 0.07 & -0.46 \\
\hline $\begin{array}{c}\text { Rate of } \\
\text { interest }\end{array}$ & -1.56 & -1.62 & -1.48 & -1.39 & -1.52 & -1.42 \\
\hline $\begin{array}{c}\text { Bureaucratic } \\
\text { procedure }\end{array}$ & -1.70 & -1.66 & -1.64 & -1.63 & -1.52 & -1.61 \\
\hline $\begin{array}{c}\text { Insufficient } \\
\text { amount }\end{array}$ & -0.53 & -0.52 & -0.64 & -0.80 & -0.52 & -0.75 \\
\hline $\begin{array}{c}\text { Pledging of } \\
\text { securities }\end{array}$ & -1.74 & -1.6 & -1.65 & -.1 .65 & -1.48 & -1.62 \\
\hline Commissions & -1.73 & -1.68 & -1.69 & -1.67 & -1.66 & -1.67 \\
\hline $\begin{array}{c}\text { Political } \\
\text { interference }\end{array}$ & -1.81 & -1.69 & -1.75 & -1.77 & -1.69 & -1.75 \\
\hline Red tapism & -1.80 & -1.68 & -1.76 & -1.78 & -1.76 & -1.77 \\
\hline $\begin{array}{c}\text { Repayment } \\
\text { procedure }\end{array}$ & -1.30 & -1.5 & -1.31 & -1.26 & -1.41 & -1.29 \\
\hline $\begin{array}{c}\text { Repayment } \\
\text { of loan }\end{array}$ & -1.73 & -1.69 & -1.64 & -1.60 & -1.52 & -1.58 \\
\hline
\end{tabular}

Source: Calculations based on field survey.

Table 7: Assigned Scores on Problems in Availing Government Loan.

\begin{tabular}{|c|c|c|c|c|}
\hline SI.No & Tested Factors & $\begin{array}{c}\text { Women } \\
\text { beneficiaries }\end{array}$ & $\begin{array}{c}\text { Men } \\
\text { beneficiaries }\end{array}$ & Total \\
\hline 1 & Delay in sanctioning loans & 4.619 & 4.026 & 9.032 \\
\hline 2 & Rate of interest & 0.004 & 0.026 & 0.000 \\
\hline 3 & Bureaucratic procedure & 0.319 & 1.538 & 1.461 \\
\hline 4 & Insufficient amount & 0.043 & 1.098 & 1.114 \\
\hline 5 & Pledging of securities & 1.432 & 2.675 & 3.799 \\
\hline 6 & Commissions & 1.219 & 0.321 & 1.153 \\
\hline 7 & Political interference & 1.736 & 0.814 & 2.332 \\
\hline 8 & Red tapism & 1.736 & 0.049 & 1.139 \\
\hline 9 & Repayment procedure & 0.323 & 0.000 & 0.203 \\
\hline 10 & Repayment of loan & 0.012 & 0.757 & 0.381 \\
\hline
\end{tabular}

Source: Calculations based on field survey. $X^{2} \cdot{ }_{05}=3.84$ for $v=1$

Table 8: Variability in Problems Faced By the Beneficiaries - Kruskal Wallis $X^{2}$ Test 
Citation: Shoba Ajithan K (2014) Perception of the Beneficiaries of PMEGP: A Micro Level Study. J Socialomics 3: 109. doi:10.4172/21670358.1000109

Page 5 of 5

loan. It has also emerged as a successful scheme in uplifting the morale of the women beneficiaries by raising their self-confidence, decision making status, improving their communicative skills and problem solving ability. This scheme has become a boon for the women, who have to earn an extra income for the family due to economic necessities. To bring in more women the authorities concerned should promote awareness about Prime Minister's Employment Generation Programme by giving wide publicity through local media, especially newspapers, radio and television.

\section{Acknowledgement}

The Author wishes to acknowledge UGC for funding the project.

\section{Reference}

1. Chennappa D (2004) Impact of the PMRY Scheme in Andhra Pradesh. SEDME 31: $41-70$.

2. Deshpande RS, Bhende MJ, Thippaiah P, Manasi S (2005) An Evaluation Study of Prime Minister's Rozgar Yojana. Research Report: 9, Agricultural Development and Rural Transformation Unit, Bangalore.

3. Shobha K (2007) Performance of Women Beneficiaries of Prime Minister's Rozgar Yojana in Coimbatore City. ProQuest Dissertations \& Theses: 246. 